\title{
NILAI PO SAPO ESEMPAY (KESETIAKAWANAN) DAN SOKKLA (KEAGAMAAN) DALAM PENENTUAN HARGA JUAL ROTI DAN KUE DI MADURA: SEBUAH STUDI FENOMADUROLOGI
}

\author{
Rusmiati Ningsih ${ }^{1}$, Robiatul Auliyah ${ }^{2}$, Achdiar Redy Setiawan ${ }^{3}$ \\ Irusmiatiningsih45@gmail.com \\ 2robiatul.aulivah@trunojoyo.ac.id \\ ${ }^{3}$ Universitas Trunojoyo Madura, Achdiar.redy17@gmail.com
}

\begin{abstract}
This research seeks to uncover the practice of selling bread and cakes in Madura. This research using qualitative methods in the process of discovery the answers, and also phenomadurological approach in the process of analysis the extending about awareness of "Aku" with Madura culture. The approach is chosen because researchers need the depth methods to reveal the reality behind the phenomenon. The research is also need the informants, there are two main informants is home business owners amounted to 2 people, as well as supporting informants that the customer amounted to 4 people. This research site was conducted at the place of home business in Jl. K Lemah Duwur Bangkalan. The results showed that the practice of determining the price of bread and cookies that occur based on the calculation of raw material costs and factory overhead costs. In addition, there are costs which made bythe invisible mark up. After exploring the cost and the markup, there is a determination of the values contained in the selling price. The values contained namely Po Sapo Esempay (Solidarity) realized with a sense of mutual help, family/ friend as an advantage over the matter, an expression of care, sharing the happiness, trust to others and also to give an attention to the situation around us. Another value that is contained is Sokkla (Religiousity), which materialized with their interests for the charity, belief in God's justice, charity as savings in the Hereafter, and surrender to God.
\end{abstract}

Keywords: Selling Price, Phenomadurology, Po Sapo Esempay (Solidarity), Sokkla (Religiousity)

\begin{abstract}
ABSTRAK
Penelitian ini berupaya untuk mengungkap praktik penentuan harga jual roti dan kue di Madura. Penelitian ini menggunakan metode kualitatif dalam proses penemuan jawaban, dan pendekatan fenomadurologi dalam proses analisis yaitu dengan mengkaitkan kesadaran mengenai "Aku" dengan kebudayaan Madura. Pendekatan tersebut dipilih karena peneliti membutuhkan kedalaman untuk mengungkap realita di balik fenomena tersebut. Informan dalam penelitian ini adadua yaitu informan utama yaitu pemilik usaha rumahan berjumlah 2 orang, serta informan pendukung yaitu pelanggan yang berjumlah 4 orang. Situs penelitian ini dilakukan di tempat usaha yaitu Jl. K Lemah Duwur Bangkalan. Hasil penelitian menunjukkan bahwa praktik penentuan harga roti dan kue yang terjadi berdasarkan perhitungan biaya bahan baku dan biaya
\end{abstract}


overhead pabrik. Selain itu,juga terdapat biaya-biaya dalam mark up yang tak kasat mata. Setelah mengeksplorasi secara mendalam dari kedua hal tersebut yaitu biaya dan mark up, maka juga terdapat nilai yang terkandung dalam penentuan harga jual.Nilainilai yang terkandung yaitu Po Sapo Esempay (Kesetiakawanan) yang terwujud dengan adanya rasa untuk saling membantu, saudara sebagai suatu keuntungan melebihi materi, ungkapan perhatian, berbagi terhadap sesama, kebahagiaan, kepercayaan, serta melihat keadaan orang sekitar. Nilai lain yang terkandung yaitu Sokkla (Keagamaan) yang terwujud dengan adanya kepentingan untuk beramal, keyakinan akan keadilan Allah, sedekah sebagai tabungan di Akhirat, serta kepasrahan kepada Tuhan.

Kata Kunci: Harga Jual, Fenomadurologi, Po Sapo Esempay (Kesetiakawanan), Sokkla (Keagamaan)

\section{PENDAHULUAN}

Salah satu kreatifitas usaha yang dilakukan oleh penduduk Indonesia yaitu usaha rumahan. Bekerja kini tidak lagi dimaknai semata hanya bekerja di Kantor atau badan usaha tertentu (www.Jurnalasia.com, 6Juni 2016). Usaha rumahan sendiri merupakan rumah tinggal yang merangkap menjadi tempat usaha yang dapat dijadikan langkah awal menjadi pengusaha. Seperti yang kita ketahui bahwa banyak pengusaha yang sukses yang memulai usaha dari rumah (Nurpeni, 2010).Memiliki usaha rumahan mempunyai banyak manfaat salah satunya menghemat investasi tempat usaha, hal tersebut terjadi karena kita tidak perlu menyewa atau membeli tempat usaha. Mmeskipun kita harus menyewa rumah, maka rumah tersebut akan menjadi semakin produktif karena tidak hanya dijadikan tempat tinggal, namun juga ladang usaha (Nurpeni,2010).

Pergeseran zaman bahkan sudah membawa tingkat kesibukan masyarakat terus meningkat sehingga masyarakat mulai berfikir untuk mencari hal-hal yang praktis termasuk dalam konsumsi. Salah satu alternatif yang dilakukan dengan mengonsumsi makanan cepat saji tanpa mengenyampingkan nilai gizi dari makanan tersebut (e Paper Koran Madura, 27 Januari 2014).Kondisi inilah yang dilihat oleh beberapa orang hingga mendatangkan kesempatan yang sangat besar bagi masyarakat yang memiliki kemampuan membuat roti dan kue. Usaha rumahan ini akan memberikan keuntungan yang besar jika dilakukan dengan perhitungan yang tepat (peluangusaharumahan.info, 2017).

Fenomena usaha rumahan dengan perhitungan harga jual hasil produksinya menajdi hal yang tidak dapat dipisahkan. Sebagian besar usaha rumahan memiliki kegiatan pokok mengolah bahan baku menjadi produk jadi, yang kemudian memasarkan hasil produknya tersebut. Cara penentuan harga dan penanganan harga memiliki cara yang berbeda-beda. Pada dasarnya penentuan harga ditargetkan untuk orientasi laba, orientasi sales, dan orientasi status (Ahmad, 2013: 148). Untuk memperoleh tujuan tersebut maka harus menambah biaya tertentu dengan mark up yang sudah ditentukan.

Harga jual terbaik adalah yang dapat memaksimumkan laba. Maksimisasi laba akan terjadi jika pada saat adanya perbedaan antara pendapatan total dengan biaya total dengan jumlah yang paling besar(Halim, Supomo, Kusufi, 2014: 133). Hal tersebut juga dipertegas oleh Dajono (2011: 33) yang menyebutkan bahwa sesuai dengan konsep 
biaya, biaya yang diproduksi merupakan biaya yang diperlukan untuk memproses produk. Dengan demikian dalam menentukan harga pokok produk, sama halnya dengan menentukan berapa biaya yang diserap untuk produk tersebut. Harga pokok produk itu sendiri masih dibedakan menjadi harga pokok proses, dan harga pokok pesanan (Mulyadi, 2012:24).

Beralih dari teori-teori tersebut, maka banyak penelitian yang meneliti tentang penentuan harga jual. Penelitian tersebut pernah dilakukan oleh Moray (2014), dalam penelitian tersebut diungkapkan bahwa harga jual menggunakan cost plus pricing dengan pendekatan full costingadalah cara yang dapat digunakan oleh UD Gladys Bakery dalam menghitung harga jual sehingga dapat bersaing dengan produk sejenis di pasaran.Penelitian senada juga dilakukan oleh Lestari (2014), penelitian ini mengungkapkan bahwa Usaha Saudara di Banyumik menerapkan perhitungan harga pokok yang masih sederhana, dan dari hasil perhitungan sederhanya, maka harga pokok yang didapat sebesar $\mathrm{Rp}$ 8.351.333,00 Namun, ketika peneliti mencoba menggunakan full costing, maka harga pokok produksinya sebesar $\mathrm{Rp} 5.796 .333,00$. Dari angka tersebut maka terlihat jelas bahwa selisih keduanya sebesar Rp 2.557.000,00. Dari hasil tersebut, peneliti menyimpulkan bahwa metode full costing lebih menguntungkan karena laba yang didapat lebih tinggi, dan biaya produksi lebih rendah.

Selain penetapan harga jual pada usaha rumahan roti dan kue, terdapat pula peneliti yang menemeneliti tentang harga jual pada usaha-usaha lainnya. Penelitian ini dilakukan oleh Sulpa (2014), ia meneliti tentang proses penentuan harga jual pada Rumah Makan Citra Minang di Makassar. Dalam penelitiannya ditemukan bahwa harga jual yang diterapkan hanya berdasarkan unsur biaya bahan baku utama saja yaitu lauk, dan menghasilkan harag jual $\mathrm{Rp}$ 16.000. Namun, ketika dihitung menggunakan cost plus pricing harga jual yang didapat $\mathrm{Rp} 17.000$ hal tersebut sesuai dengan keinginan perusahaan yang menetapkan mark up sebesar 60\%. Soei (2014) juga meneliti tentang penetuan harga jual pada UD. Sinar Sakti, dalam penelitian tersebut diungkapkan bahwa perusahaan tersebut menggunakan metode harga jual yang diterapkan produsen, dimana harga jual mengikuti harga pasar yang telah ditetapkan oleh usaha dagang sejenis lainnya. Perusahaan tidak menghitung semua komponen biaya, sehingga harga jual yang ditetapkan perusahaan lebih tinggi daripada harga jual yang dihitung berdasarkan cost plus pricing.

Hal tersebut memberikan pemahaman bahwa dalam penentuan harga jual hanya terbelenggu oleh nilai-nilai kuantitatif yang dianggap lebih rasional dalam menciptakan keuntungan berupa materi (Amaliah, 2016). Sesuatu yang didominasi oleh pola pikir kapitalisme akan menempatkan materi sebagai alat dan tujuan utamanya dalam beroperasi, sehingga fokus kegiatan usahanya hanya meningkatkan pendapatan dan meminimalisasi biaya apapun konsekuensinya, karena itulah tujuan bisnisnya (Efferin, 2016: 12).

Di sisi lain, tidak semua usaha hanya mementingkan materi sebagai tujual awalnya. Hal ini terlihat dalam pergerakan penelitian harga yang awalnya didasarkan pada aspek-aspek kuantitatif, kini mengalami pergeseran. Seperti penelitian yang dilakukan Zalshabila (2012), yang meneliti harga pokok produksi pada pedagang bakso di kota Malang, dan hasil dari penelitiannya tersebut, ia menemukan bahwa ternyata dalam penentuan harga jual tidak terefleksikan dari harga pokok produksi, namun ada nilai-nilai lain yaitu tepo seliro, mangan ora mangan seng penting ngumpul, dan nerimo ing pandum. Penelitian senada juga dilakukan oleh Amaliah (2016), ia menemukan adanya nilai Tri Hita Karana dalam penentuan harga jual yang diimplementasikan oleh 
masyarakat transmigran Bali di Bolaang Mongondow. Dalam nilai tersebut merefleksikan bahwa adanya nilai ketundukan kepada Sang pencipta, pelestarian lingkungan, dan gotong-royong.

Amaliah (2014) juga meneliti tentang konsep harga jual yang dilakukan oleh komunitas Papalele masyarakat Maluku. Dalam penetapan harga jualnya tersebut terdapat nilai pela (gandong)yang yaitu adanya nilai kejujuran, keadilan, cinta kasih, dan kepercayaan. Nilai tersebut menggambarkan bahwa dalam penetapan harga tidak semata-mata pada nilai materi namun juga terdapat nilai non materi di dalamya. Penelitian harga jual juga dilakukan oleh Alimuddin (2011) berdasarkan pada keyakinan (islam). Penlitiannya menemukan bahwa sebenarnya tidak ada gunanya menetapkan harga jual karena yang menentukan kualifikasi pembeli adalah Sang Maha pemberi Rezeki. Jika pembeli berasal dari kalangan yang mampu dan memiliki kepribadian yang baik maka kemungkinan besar akan membayar sama atau lebih besar dari harga yang berlaku umum. Harga jual semacam ini disebut pricing by buyers.

Dari penelitian tersebut, peneliti memandang bahwa ternyata penentuan harga jual tidak selalu berupa materi. Pernyataan peneliti tersebut didukung oleh Efferin $(2016,15)$ bahwa usaha yang dijalankan berdasarkan spiritual memiliki tujuan utama yang melampaui kesuksesan materi sebagai landasan operasinya, namun juga memberikan kebahagiaan kepada seluruh stakeholders.

Berdasarkan penelitian-penelitian sebelumnya, peneliti tertarik untuk meneliti harga jual roti dan kue di Madura yaitu usaha rumahan roti dan kue, karena pada dasarnya orang Madura memiliki sifat pembawaan Junel (berkewirausahaan) dan memiliki dasar ciri-ciri keindustrian (Rifai, 2007: 226). Penelitian ini berangkat dari praktik bisnis pada Usaha Rumahan Roti dan Kue Hj. Rohimah serta Usaha Rumahan Roti dan Kue Hatimah. Kedua usaha rumahan tersebut memiliki keunikan tersendiri karena selain tempatnya yang bersebelahan atau berada pada satu halaman, keduanya merasa tidak terdapat persaingan dalam menjalani usahanya. keduanya memiliki keunikan dalam penentuan harga jual roti dan kuenya, namun harga jual yang dipatok oleh mereka tidak merusak nilai pasaran roti dan kue. Selain itu, usaha rumahan tersebut masih mengedepankan nilai-nilai kearifan lokal dalam penetapan harga jualnya tersebut.

Dari fenomena-fenomena tersebut maka peneliti ingin mengetahui bagaimana konsep harga jual yang diterapkan dalam Usaha rumahan Roti dan Kue di Madura? Dan Nilai-nilai apakah yang terkandung di dalam penentuan harga tersebut? Hal tersebut yang kemudian menggelitik rasa ingin tahu untuk mengeksplorasi sesuatu di balik penentuan harga roti dan kue tersebut.

Berangkat dari rasa keingintahuan peneliti terhadap praktik penentuan harga jual yang syarat akan nilai budaya, maka yang menjadi rumusan masalah bagi peneliti adalah bagaimana konsep harga jual yang diterapkan dalam Usaha Rumahan Roti dan Kue di Madura?. Dari pertanyaan pertama tersebut, maka muncul pertanyaan selanjutnya yaitu nilai-nilai apakah yang tersirat dalam penentuan harga jual dalam Usaha Rumahan tersebut?

Penelitian ini bertujuan untuk mencari informasi-informasi terbaru terkait tentang penentuan harga jual karena semakin maraknya bisnis yang hanya berorientasi pada laba. Penelitian ini juga bertujuan untuk membuka hati para pembisnis, calon pembisnis termasuk mahasiswa bahwa dalam penentuan harga jual masih mementingkan nilai-nilai lain selain laba.

Penelitian ini diharapkan dapat memberikan kontribusi. Pertama, memberikan tambahan informasi kepada semua pihat terutama pemilik usaha rumahan dalam 
menerapkan harga jual.Kedua, untuk mahasiswa, agar dapat menambah wawasan bagaimana cara menentukan harga jual suatu produk. Ketiga, memberikan kontribusi metodologi penelitian.

\section{LANDASAN TEORI}

\section{Pandangan dalam Penentuan Harga Jual}

Penentuan harga jual pada dasarnya ditentukan oleh kekuatan permintaan dan penawaran di pasar, oleh karena itu biaya bukanlah penentu untuk menetapkan harga. Namun, dilema yang terjadi adalah permintaan konsumen atas produk atau jasa bukan hal yang mudah untuk ditentukan, karena itu manajer akan mengalami ketidakpastian. Satu-satunya faktor yang memiliki kepastian yang tinggi adalah biaya, karena biaya akan memberikan batas bawah mengenai harga jual tersebut harus ditentukan (Mulyadi,1993:347). Lebih lanjut Halim, Supomo, Kusufi $(2014,125)$ juga berpendapat bahwa harga jual lebih banyak ditentukan oleh kekuatan permintaan dan penawaran di pasaran, hal tersebut terjadi jika suatu produk dihasilkan oleh banyak perusahaan, sehingga perusahaan tidak dapat secara langsung mempengaruhi tinggi rendahnya harga jual.

\section{Faktor-Faktor yang mempengaruhi Harga Jual}

Faktor-faktor yang mempengaruhi harga jual dapat berasal dari faktor lingkungan internal ataupun eksternal. Faktor tersebut terdiri dari faktor bukan biaya dan faktor biaya. Faktor bukan biaya memang sulit diukur namun harus dipertimbangkan dalam penetuan harga jual. Faktor tersebut terdiri dari elastisitas harga permintaan, faktor ini penting karena setiap perubahan harga akan menyebabkan perubahan kuantitas. Selain itu, struktur pasar, karena harga jual disusun berdasarkan tipe pasar yang dihadapi perusahaan. Selain faktor bukan biaya, terdapat pula faktor biaya. Perusahaan dipandang sebagai suatu sistem yang memproses masukan menjadi keluaran berupa sumber ekonomi lain yang nilainnya lebih tinggi. Tanpa informasi biaya maka perusahaan tidak mempunyai ukuran yang jelas apakah masukan yang dikorbankan memiliki nilai yang lebih tinggi atau rendah daripada nilai keluarannya (Mulyadi, 2012: 10). Biaya dapat digolongkan ke dalam objek pengeluaran, Fungsi pokok dalam perusahaan, hubungan biaya dengan sesuatu yang dibiayai, perilaku biaya dalam hubungannya dengan volume kegiatan, dan jangka waktu manfaatnya. Namun, Ahmad (2013) juga menyatakan bahwa terdapat faktor lain selain pasar dan biaya.

\section{Metode Penentuan Harga Jual}

Metode penentuan harga jual berdasarkan biaya sering disebut cost plus pricing. Cost plus adalah biaya tertentu ditambah dengan mark up yang diinginkan. Terdapat 2 metode yaitu full costing dan variable costing.

Rumus Full costing yaitu:

Biaya bahan baku

Biaya tenaga kerja langsung

Biaya overhead variabel

Biaya overhead tetap

Jumlah

Mark-up $=\ldots \%$ xp $x x x$
$\operatorname{Rp} x x x$

$\operatorname{Rp} x x x$

Rp xxx

$\underline{\operatorname{Rp} x x x}$

Rp xxx

$\underline{\mathrm{Rp} x x x}$ 
Harga jual per unit

Rp xxx

Rumus Variable costing yaitu:

Biaya bahan baku

$\operatorname{Rp} x x x$

Biaya tenaga kerja langsung

Biaya overhead variabel

Biaya penjualan dan administrasi variabel

Jumlah

Mark-up $=\ldots \%$ x Rp xxx

Harga jual per unit

$\operatorname{Rp} x \times x$

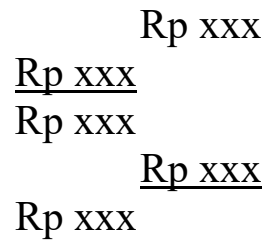

\section{METODE PENELITIAN}

\section{Pendekatan Penelitian}

Upaya untuk menelusuri praktik dan nilai yang terkandung di balik penentuan harga jual pada Usaha Rumahan Roti dan Kue Hj. Rohimah, serta Usaha Rumahan Roti dan Kue Hatimah sedikit banyak dipengaruhi oleh kebiasaan dan nilai-nilai yang terkandung di dalam masyarakat. Gaya penelitian kualitatif dianggap paling cocok untuk digunakan dalam penelitian ini karena bertujuan untuk mengetahui nilai-nilai yang dianut oleh pemilik usaha rumahan tersebut sehingga memiliki keunikan dalam penentuan harga jualnya.

Sejalan dengan pengertian tersebut, Maleong (2014) berpendapat bahwa :

"Penelitian kualitatif adalah penelitian yang bermaksud untuk memahami fenomena tentang apa yang dialami oleh subjek penelitian misalnya perilaku, persepsi, motivasi, tindakan dll secara holistik, dan dengan cara deskripsi dalam bentuk katakata dan bahasa, pada suatu konteks khusus yang alamiah dan dengan memanfaatkan berbagai metode alamiah".

Penelitian kualitatif menekankan pada aspek kualitas, tidak seperti kata kuantitatif yang menekankan pada kuantitas (Kamayanti: 2016).

Fenomenologi merupakan cara yang sesuai untuk mengetahui berbagai jawaban atas rasa penasaran peneliti. Fenomenologi dianggap sesuai karena praktik penentuan harga jual serta nilai-nilai lain yang terkandung dalam praktik tersebut, hanya pemilik usaha rumahan tersebutlah yang mengetauhinya. Fenomenolog bertugas untuk mengupas secara mendalam permasalahan yang akan diteliti, dan mengajukan pertanyaaan hingga tidak ada pertanyaan lagi yang dapat diungkapkan. Menurut Kamayanti (2016) fenomenologi adalah mencari jawaban secara mendalam melalui informan / "Aku" yang dianggap didalam bukunya yaitu :

“..Oleh karena itu "Aku disini bukan pengalaman, namun yang mengalami; "Aku” bukan aksi namun yang melakukan"

Asumsi manusia sebagai "Aku", merupakan keunikan yang ada didalam fenomenologi, karena fenomenologi berpusat pada manusia atau informan penelitian.

Penelitian ini tidak hanya berhenti pada tahap fenomenologi, namun akan dikaitkan dengan kebudayaan di Madura. Dari sekian banyak definisi yang ditawarkan oleh orang, secara sederhana kebudayaan dapat diartikan sebagai keseluruhan 
pengejawantahan batin, pikiran, dan akal budi suatu suku bangsa yang terakumulasi berdsarkan pelajaran yang tumbuh dari pengalaman hidupnya, yang merupakan suatu ciri dan kemampuan yang membedakan manusia dari binatang. Sejarah nasional Indonesia menunjukkan bahwa perkembangan kebudayaan dan peradaban orang Madura menapaki suatu lintasan yang sama dengan kebanyakan suku lainnya di Indonesia, namun faktor lingkungan menyebabkan perbedaan hasil yang dicapai. Seperti yang dialami suku lainnya, budaya dan peradaban orang Madura sedang berjuang keras untuk mencoba bertahan di tengah derasnya arus modernisasi oleh gencarnya peradaban barat, dan menggebunya upaya menyatukan pasar dunia melalui gerakan globalisasi (Rifai, 2007: 41).

Kebudayaan Madura tersebutlah yang melahirkan metodologi Fenomadurologi karena orang Madura sangat mencintai budayanya, hal tersebut terbukti dalam hal religi, citra kepatuhan, ketaatan, kefanatikan orang madura pada agama Islam yang dianut sudah lama terbentuk. Selain itu,adanya pembawaan yang khas dari orang madura yang merupakan sekumpulan kodrat, bakat, talenta, dan kecenderungan batin yang melekat sejak lahir, dan akan mempengaruhi segenap pikiran, perkataan, dan perbuatan seumur hidupnya (Rifai, 2007: 199).

\section{Situs Penelitian}

Situs penelitian ini adalah pemilik usaha rumahan roti dan kue khususnya Usaha Rumahan Roti dan Kue Hj. Rohimah dan Usaha Rumahan Roti dan Kue Ibu Hatimah. Lokasi usaha tersebut di Jalan K. Lemah Duwur Gg VIII Bangkalan. Kepadatan penduduk di daerah tersebut membuat lokasi ini menjadi strategis karena kebutuhan penduduk terhadap roti dan kue, terlebih jika terdapat acara-acara di rumah penduduk, maka yang menjadi sasaran untuk memesan adalah kedua usaha rumahan tersebut.

\section{Informan Penelitian}

Pemilihan informan tidak dibidikkan kepada semua yang memiliki usaha namun ada beberapa kriteria yang dipertimbangkan. Kriteria pemilihan informan yaitu pemilik usaha yang sudah lama beroperasi, serta mempertimbangkan pulaseberapa banyak produksinya setiap hari untuk menunjukkan kelancaran usaha. Harga jual menjadi salah satu hal yang penting karena akan menunjukkan seberapa besar pendapatan yang diperoleh. Serta, peneliti juga memilih informan yang memiliki keunikan dalam menjalani usaha rumahan tersebut. Pertama, Hj. Rohimah yang menjalani usaha rumahan selama 26 tahun. Selain menjual sendiri roti dan kuenya, beliau juga menjadi supplier bagi pedagang-pedagang di pasar, beliau juga menerima pesanan. $\mathrm{Hj}$. Rohimah mampu naik haji bersama suami dari hasil usahanya tersebut. Kedua, Ibu Hatimah yang merupakan pemilik usaha rumahan selama 27 tahun, beliau juga merupakan supplier bagi pedagang-pedagang pasar. Produksinya setiap hari 500 pcs bahkan ketika bulan Ramadhan bisa mencapai 1.000 pcs, dengan pendapatan rata-rata Rp 500.000 hingga Rp 1.000.000 per harinya.

\section{Teknik Pengumpulan Data}

Teknik pengumpulan data yaitu observasi, wawancara, dan dokumentasi. Semua hal tersebut dilakukan di Rumah informan utama sekaligus yang dijadikan tempat usaha, selain itu juga dilakukan di pasar tempat pelanggan berjualan, serta di rumah tetangga yang sudah terbiasa berinteraksi dengan informan. 


\section{Teknik Analisis Data}

Ketika data sudah terkumpul, maka tugas peneliti selanjutnya adalah menganalisis data tersebut. Teknik analisis data fenomenologi transcendental menurut Kamayanti (2016) yaitu ada beberapa kunci yang harus dipahami yaitu : 1) Noema, 2) Noesis, 3) Epoche (Bracketing), 4) Intentional Analysis, 5) Eidetic Reduction. Setelah proses transkip wawancara selesai maka hal selanjutnya yaitu dispesifikkan lebih detail dengan intentional analysis yang terdiri dari dua bagian noema yaitu ungkapan pertama informan, dan noesis kesadaran terdalam informan. Dari noesis tersebut, maka akan dikaitkan dengan kebudayaan orang madura yang sudah menjadi pengejawantahan sehingga dapat dikethaui bagaimana penentuan harga jual yang diterapkan oleh sosok manusia Madura.

\section{HASIL PENELITIAN}

\section{Potret Penentuan Harga Jual Roti dan Kue Secara Kasat Mata}

Setiap usaha tidak terkecuali usaha rumahan pasti terbentur dengan biaya produksi yang menjadi awal dalam penentuan harga jual. Sebelum menentukan harga jual, maka harus mengetahui biaya apa saja yang ditanggung dalam proses produksinya yaitu biaya bahan baku, biaya tenaga kerja, dan biaya overhead pabrik (Halim, Supomo, Kusufi, 2014: 130). Hj. Rohimah sebagai pemilik usaha berhasil mencuri perhatian peneliti. Kue paling banyak yang stiap harinya d produksi adalah dadar. Dalam pembuatan dadar, tentunya memerlukan bahan-bahan tertentu. Bahan yang diperlukan dalam $3 \frac{1}{2} \mathrm{~kg}$ yaitu terlihat pada gambar berikut:

Tabel 1. Biaya Bahan Baku Dadar

\begin{tabular}{|c|c|c|}
\hline Bahan & Kuantitas & Harga \\
\hline Tepung & $31 / 2 \mathrm{~kg}$ & $\mathrm{Rp} 24.500$ \\
\hline Kelapa & $80 \mathrm{~ns}$ & $\mathrm{Rp} 12.000$ \\
\hline Gula & 6 ons & $\mathrm{Rp} 7.000$ \\
\hline Telur & 2 & $\mathrm{Rp} 2.000$ \\
\hline Pewarna & Secukupnya & $\mathrm{Rp} 2.000$ \\
\hline \multicolumn{2}{|c|}{ Jumlah } & $\mathrm{Rp} \mathrm{47.500}$ \\
\hline
\end{tabular}

Sumber: Data olahan, informan Hj. Rohimah

Beralih dari bahan baku yang dibutuhkan dalam proses produksi dadar, ternyata masih terdapat biaya-biaya lain yang dikeluarkan yaitu plastikpembungkus dadar. Berikut penuturan informan:

"Iyeh UPP, UPP nah seanoh neng 150, 4.500".

(iya UPP, UUP nya itu neng 150, harganya 4.500.)

Selain biaya untuk plastik, H.j Rohimah juga memperhitungkan gas yang digunakan selama proses produksi yaitu sekitar Rp 10.000:

“Gas sah jiyah, yeh mon sittong lo' sampe'. Yeh sekitaran 10.000 jiyah”.

(kalau gas, ya kalau satu gak sampek. Ya paling sekitar 10.000 itu) 
Dari ungkapan $\mathrm{Hj}$. Rohimah tersebut ternyata biaya overhead yang dikeluarkan oleh $\mathrm{Hj}$. Rohimah terlihat pada gambar berikut:

Tabel 2, Biaya Overhead Pabrik dadar

\begin{tabular}{|l|l|}
\hline Plastik & $\operatorname{Rp~4.500~}$ \\
\hline Gas & $\operatorname{Rp~} 10.000$ \\
\hline Jumlah & $\operatorname{Rp~} 14.500$ \\
\hline
\end{tabular}

Sumber: Data olahan, informan Hj. Rohimah

Setelah mendapatkan gambaran yang jelas mengenai biaya-biaya yang dikeluarkan selama proses produksi yang sudah diceritakan oleh informan. Maka harga pokok produksi yang dikeluarkan oleh $\mathrm{Hj}$. Rohimah yaitu Biaya Bahan Baku dan Biaya Overhead Pabrik Variabel

Tabel 3, Harga Pokok Produksi Dadar

$$
\begin{aligned}
& \text { Harga Pokok Produksi= Biaya Bahan Baku + Biaya Overhead Pabrik Variabel } \\
& =\operatorname{Rp} 47.500+\operatorname{Rp} 14.500 \\
& =\operatorname{Rp} 62.000
\end{aligned}
$$

Dalam gambaran tersebut dapat terlihat secara kasat mata bahwa dalam pembuatan dadar $3 \frac{1}{2} \mathrm{~kg}$ memerlukan biaya $\mathrm{Rp}$ 62.000. Dalam $3 \mathrm{~kg}$ tersebut, maka akan menghasilkan 160 pcs dadar.

Setelah ditanya bagaimana menentukan harga roti atau kuenya tersebut, beliau menjawab :

“1.000 etange'aghin 800”.

(1.000 dijual ke pelanggan 800).

"Spiku 1.300, ejuwal 1.500. Blackforest 1.800, ejuwal 2.000".

(Spiku 1.300, dijual 1.500, Blackforest 1.800 dijual 2.000)

Dalam menentukan harganya tersebut, terdapat banyak faktor yang dipertimbangkan oleh $\mathrm{Hj}$. Rohimah seperti harga roti dan kue yang terdapat di pasaran, karena tidak dapat dilupakan bahwa usaha rumahan terutama dalam roti dan kue memiliki banyak pesaing. Hal ini termasuk dalam struktur pasar persaingan sempurna dimana penjual tidak dapat menetapkan harga dan mereka adalah penerima harga.

Meskipun usaha rumahan yang dimiliki oleh $\mathrm{Hj}$. Rohimah tidak dapat menentukan mark up yang seharusnya ditentukan dalam bentuk persentase seperti yang disebutkan dalam akuntansi biaya ataupun akuntansi manajemen. Namun, beliau juga memiliki faktor-faktor lain selain biaya dalam penentuan harga jualnya. Sehingga penentuan mark up dalam penetapan harga jual tidak dapat dilihat secara kasat mata karena tidak ditetapkan secara kuantitatif.

Meninggalkan $\mathrm{Hj}$. Rohimah dengan perhitungan biaya yang dikeluarkan selama proses produksi serta harga jual setiap roti dan kuenya tersebut. Peneliti beranjak kepada usaha rumahan milik Ibu Hatimah.Beliau mengatakan bahwa kue yang paling banyak di produksi adalah kue yang kecil seperti terang bulan, donat, boling. Ketika ditanya biaya-biaya yang dikeluarkan selama proses produksi, ibu Hatimah menjelaskan bahan-bahan dalam pembuatan terang bulan. Berbeda dengan $\mathrm{Hj}$. Rohimah yang 
langsung memperhitungkan sebanyak $3 \frac{1}{1} 2 \mathrm{~kg}$ dadar, maka yang terjadi di usaha rumahan milik ibu Hatimah adalah beliau menghitung biaya dengan cara 1 resep.

Beliau secara sadar memperhitungkan biaya-biaya yang dikeluarkan dalam pembuatan $1 \mathrm{~kg}$ terang bulan. Biaya tersebut terdiri dari biaya bahan baku dan biaya overhead, yang terlihat pada gambar berikut ini:

Tabel 4, Biaya Bahan Baku dan iaya Overhead Pabrik Terang Bulan

\begin{tabular}{|c|c|c|c|}
\hline Biaya & Bahan & Kuantitas & Harga \\
\hline \multirow[t]{7}{*}{ Biaya Bahan Baku } & Tepung & $1 \mathrm{~kg}$ & 7.000 \\
\hline & Gula & & 3.000 \\
\hline & Telur & 2 & 2.000 \\
\hline & Mentega & $1 / 4 \mathrm{~kg}$ & 4.000 \\
\hline & Kelapa & & 2.000 \\
\hline & Hermifan & & 1.000 \\
\hline & Meses & & 2.000 \\
\hline \multirow{2}{*}{$\begin{array}{c}\text { Biaya Overhead } \\
\text { Pabrik }\end{array}$} & Plastik UPP & & 1.000 \\
\hline & Gas & & 1.000 \\
\hline Jumlah & & & 23.000 \\
\hline
\end{tabular}

Sumber: Data olahan, Informan Ibu Hatimah

Setelah mendapatkan gambaran yang jelas mengenai biaya-biaya yang dikeluarkan dalam pembuatan terang bulan tersebut maka harga pokok produksi yang dikeluarkan oleh ibu Hatimah untuk 1 resep terang bulan yaitu terdiri dari biaya bahan baku dan biaya overhead pabrik.

Tabel 5, Harga Pokok Produksi Dadar

Harga Pokok Produksi $=$ Biaya Bahan Baku + Biaya Overhead Pabrik

$$
=21.000+2.000
$$$$
=23.000
$$

Dari gambaran tersebut terlihat jelas bahwa dalam pembuatan terang bulan sebanyak 1 $\mathrm{kg}$ memerlukan biaya sebesar Rp 23.000. Dalam $1 \mathrm{~kg}$ tersebut menghasilkan 40 pcs terang bulan.

Setelah mengetahui biaya-biaya yang dikeluarkan ketika proses produksi, kemudian pertanyaan yang sama terlontar dari peneliti yaitu bagaimana cara ibu Hatimah menentukan harga-harga rotinya tersebut. Ibu Hatimah dengan senang hati menjawab:

" $\{$ Nentuin dhibi'\}, mon \{kerannah olle bathe\} yeh seriyah, mon bathenna korang eonggheaghin. Yeh enjek lok eongga'aghin jhek le olle bathe jiyah. Kan \{alhamdulillah banyak 17.000\}".

(\{Nentuin sendiri\}, kalau \{sekiranya dapat untung\} ya segitu, kalau untungnya kurang ya dinaikkan. Ya nggk gak dinaikkan, kan sudah dapat untung itu. Kan \{alhamdulillah 17.000\}) 
Kemudian beliau melanjutkan:

"Iyeh lakar \{mon neng pasar\} oreng menta sariya ye sariya, yeh \{lakar toroaghin\}, mon lok etoroaghin ye oreng lo' melle larang lun ekuwah bik oreng legghi',".

(Iya memang\{kalau di pasar\} orang minta berapa, ya berapa gitu, ya \{memang mengikuti\}, kalau gak diikuti ya orang gak kira beli kemahalan gitu nanti).

Dari ceritanya tersebut beliau menyatakan bahwa harga jualnya ditentukan sendiri yang penting mendapatkan hasil, namun beliau juga masih melihat harga dipasaran karena jika tidak melihat harga di pasaran beliau khawatir roti dan kuenya tidak laku karena pembeli menganggap harga tersebut terlalu mahal.Beliau tidak menentukan berapa \% keuntungan yang ingin di dapatkan. Dari situlah beliau memberi harga normal Rp1.000, dan untuk pelanggan mendapatkan harga $\mathrm{Rp} 800$. Untuk kue yang harga normalnya Rp 1.500 , akan dijual Rp 1.250 kepada pelanggan

\section{Mark Up : Biaya yang dibutuhkan dalam Penentuan Harga jual yang Tak Kasat Mata}

Setiap usaha rumahan, yang bergerak di bidang manufaktur, terlebih jika setiap harinya memproduksi roti dan kue tentunya tidak akan terlepas dari biaya listrik yang dikeluarkan. Tenaga listrik yang digunakan tersebut secara otomatis akan menjadi biaya karena digunakan ketika memproduksi roti dan kue. Namun yang terjadi pada usaha rumahan milik ibu Hatimah adalah sebaliknya, beliau tidak bisa menghitung seberapa besar biaya listrik yang dikeluarkan untuk keperluan produksinya tersebut, beliau menceritakannya:

"Reken le 500 hehehehe \{listrik, mekser\} kan le sittong \{wes lok usa\} ja' le 500 kan bulenan".

(Anggap saja 500 hehehehe \{listrik, mixer\} kan sudah jadi satu dengan listrik sudah \{gak usah saja\} wong hanya 500 kan bulanan).

Kemudian beliau melanjutkan:

"Le \{benya'an se eangghuy seroma\} reken jiyah".

(Iya lebih banyak yang digunakan se rumah itu).

Pada titik ini pemahaman "Aku" atas ibu Hatimah adalah "Aku tidak menghitung biaya listrik, karena menganggap biaya tersebut terlalu murah dan sudah di masukkan ke dalam biaya bulanan, karena Aku sadar biaya tersebut lebih banyak digunakan untuk keperluan rumah".

$\mathrm{Hj}$. Rohimah juga tidak memperhitungkan biaya listriknya sebagai biaya dalam proses produksi. Hal tersebut terjadi karena beliau sudah menyatukan biaya tersebut ke dalam biaya bulanan, seperti yang dikatakannya:

“Engko' mon listrik, mekser kabbhi jiyah abi' 270.000 per bulen neng. Poko' \{segalanna\} bik engkok \{epesittong\}, kipas lok toman mateh neng, 6 jeh non stop lo' toman mateh. Abi'eng 270.000 jiya neng".

(Saya kalau listrik, mixer semua itu habis 270.000 per bulan neng. Pokok \{semuanya\} itu saya $\{$ satukan\}, kipas gak pernah mati, 6 itu non stop gak pernah mati. Semuanya itu habis 270.000 neng). 
Kemudian beliau melanjutkan:

"Yeh ella, jhe'reng anoh jiyah, \{le engampongaghin ber seleberreh\}. Poko' sateya listrik jiyah le \{erangkummaghin sebulen\}".

(Ya jangan, kan itu sudah, ee \{sudah di ambil dari semuanya\}. Pokok sekarang listrik itu sudah \{dirangkum sebulan\}).

Pada titik inilah, pemahaman "Aku" atas $\mathrm{Hj}$. Rohimah adalah "Aku menghitung biaya listrik per bulan namun tidak memisahkan dengan biaya yang digunakan untuk produksi, karena Aku sadar bahwa biaya tersebut sudah mengambil dari semuanya dan dirangkum dalam sebulan".

Melihat dari aktifitas usaha rumahan tersebut yang selalu mengantarkan roti dan kuenya untuk pelanggan, peneliti juga tertarik untuk bertanya mengenai biaya bensin. Kemudian dengan senang hati $\mathrm{Hj}$. Rohimah menjelaskan:

'Poko' engko' bensinna jiyah neng ke pasar bik ter ngaterraghin, \{kapan 20.000 jiyah deddhi 3 areh\}. Tape yeh jiyah \{ghik eangguy neng dek masjid\} dek kammah ruwah bik aba. Mon engkok kan sekali jalan, ke pasar yeh pas mole lok man kamman pole"

(Pokok saya itu bensinnya neng untuk ke pasar dan ngantarkan kue, \{kalau 20.000 itu jadi 3 hari\}. Tapi ya itu \{masih dipakai ke masjid\}, kemana gitu sama aba. Kalau saya kan sekali jalan, ke pasar terus pulang, yaudah gak kemanamana lagi).

Kemudian beliau melanjutkan:

"Enje', \{jhek le bensih apah kadheng 3 areh, 4 areh\}.,

(Nggak, wong \{cuma bensin apa kadang 3 hari, 4 hari\}).

Pada titik ini pemahaman "Aku" atas $\mathrm{Hj}$. Rohimah adalah "Aku menghitung berapa biaya bensin yang digunakan dalam 3 hari, namun tidak memperhitungkan untuk aktifitas usaha, karena aku sadar bahwa bensin tersebut tidak semata-mata digunakan untuk usaha, namun juga untuk keperluan pribadi".

Beralih dari biaya tersebut, peneliti juga mempertanyakan tentang biaya tenaga kerja. Ibu Hatimah menceritakan tentang biaya tenaga kerja selama menjalani usahanya tersebut:

"Enje' \{engko' alakoh dhibhik\}"

(Nggak, \{saya kerja sendiri\}).

Beliau tidak menghitung biaya tenaga kerja dengan anggapan bahwa beliau bekerja sendiri.

Dari uraian di atas, maka dapat diketahui bahwa terdapat tiga biaya yang tidak diperhitungkan secara kuantitatif dalam pembuatan roti dan kue karena pemilik merasa bahwa biaya tersebut tidak hanya digunakan untuk usaha, namun untuk keperluan pribadi juga, akan tetapi biaya tersebut sudah diambil dari mark up. Biaya-biaya tersebut terdiri dari Biaya listrik, biaya bensin, dan baiay tenaga kerja. 
Nilai Po Sapo Esempay (Kesetiakawanan) di Balik Penentuan Harga Jual

Nilai Po Sapo Esempay (Kesetiakawanan) ibarat kawan senasib sepenanggungan yang menunjukkan persahabatan sejati yang sangat erat dan akrab, sehingga akan menyebabkan kesenangan yang satu akan dirasakan juga oleh lainnya, begitu juga sebaliknya kesusahan akan dibagi-bagi sehingga juga akan ikut merasa dirugikan.

Nilai ini terlihat ketika bahan-bahan naik, maka pemilik usaha rumahan tidak akan menaikkan harga roti dan kuenya:

'Iyeh mon tellor enga' satiya kan ongghe neng 2 ebuh. Enje' \{engko' le lo' mentah ongghe\} berarti engkok le \{ngorange ollena\} deiyeh".

(Iya kalau telur sekarang kan naik neng 2 ribu. Enggak \{saya gak minta naik\} juga, berarti \{ya mengurangi untung\} gitu).

Kemudian beliau melanjutkan:

"Yella neng \{nyamana manossa\} engko' reh terro, terro ( sambil mengambil roti yang hampir digerumuti semut) ye \{male abentoh\} neng neser oreng neng. Apalagi se melle oreng ma roma kan neser yeh tekerjet san depak. Se penteng engkok le lok rogi ke tang bheden, misallah olle 10 ebuh per roteh, pas deddhi 8 ebuh, Ye dhinah lo' arapah. Kan neser neng, engkok \{neser ke pelanggan\}".

(Ya \{namanya manusia\} saya ini ingin, ingin (sambil mengambil roti yang hampir digerumuti semut) ya \{biar bisa bantu\} neng, kasihan orang. Apalagi yang beli pas orang sini kan kasihan ya. Yang penting tidak bikin rugi ke badan saya, misalnya dapat 10ribu per roti, terus jadi 8 ribu per roti, ya gak apa-apa. Kan \{kasihan neng, saya kasihan ke pelanggan\}).

Pada titik inilah, kesadaran "Aku" atas $\mathrm{Hj}$. Rohimah adalah "Aku sadar harga bahan roti dan kue naik namun tidak menaikkan harga roti dan kue, lalu lebih memilih mengurangi untung, karena Aku sadar sesama manusia harus saling membantu".

Selain terlihat pada penentuan harga yang tetap meski bahan naik, nilai ini jugaterlihat ketika $\mathrm{Hj}$. Rohimah memberikan harga yang lebih murah kepada pelanggannya yang menjual kembali di pasar, berikut penuturannya:

"Iyeh \{juwalla\} 1.000, \{tangghe'eng\} 800”.

(iya \{jualnya\} 1.000, ke \{pelanggan\} 800).

Kemudian beliau melanjutkan :

"Iyeh mon engko' \{insyaallah benyaan neserra\} ke pelanggan deiyeh apah pole pas ngebeh ana'eng, dhinah maghi jhejen apaah le pas jhuluaghin deiyeh. Pagghun benyaan ghentenna".

(Iya kalau saya \{insyaallah lebih banyak kasihannya\} ke pelanggan, apalagi pas bawa anak, sudah meskipun kue apa saja pasti saya kasih. Tetap lebih banyak gantinya kok).

kesadaran "Aku" atas $\mathrm{Hj}$. Rohimah adalah "Aku memberikan harga Rp 800 kepada pelanggan, karena sudah merasa bahwa pelanggan-pelanggannya sudah menyatu di dalam pasar, hal tersebut di lakukan karena Aku memiliki rasa perhatian terhadap pelanggan"

Pernyataan Hj. Rohimah tersebut didukung oleh pelangganya yaitu umi Sulastri yang sudah berlangganan selama 8 tahun: 
"Deri Hj. Rohimah olle 800"

(dari hj. Rohimah 800)

Beliau melanjutkan:

"Ejuwal 1.000"

(dijual 1.000)

Dari hasil penjualannya tersebut beliau bisa mendapatkan penghasilan sampai 1 juta jika ramai pasaran, namun jika sepi beliau hanya bisa mendapatkan 100 ribu bahkan 200 ribu.

Hj. Rohimah juga sudah merasa bahwa dari harga jualnya tersebut beliau bisa mememenuhi kebutuhannya, keluarga, dan orang sekitarnya yaitu masih bisa memberi kepada anak yatim, orang tarawih, dan orang yang membutuhkan lainnya.

Hal tersebut juga terjadi pada ibu Hatimah, beliau memberikan harga Rp 800 kepada pelanggannya:

“Iyeh engkok \{pagghun\} 1.000 \{neser\} tangghe'eng 800 \{neser\}".

(Iya saya \{tetap\} 1.000 \{kasihan\}, ke pelanggan 800 \{kasihan\}).

Kata neser (kasihan) yang disebut berkali-kali, menjadikan kunci bagi peneliti untuk mengetahui kesadaran terdalam informan mengapa merasa kasihan kepada pelangganya tersebut sehingga berpengaruh terhadap penentuan harga jualnya:

"Yeh male pade olle, \{male padeh ngakan\} oreng neng".

(Ya supaya sama-sama dapat, \{supaya sama-sama makan\} neng).

Kesadaran ibu Hatimah pada titik ini adalah "Aku memberikan harga lebih murah kepada pelanggan karena merasa kasihan, hal tersebut dilakukan karena Aku sadar bahwa pelanggan menjual kembali agar sama-sama mendapat untung, sama-sama bisa makan, sehingga bisa berbagi kebahagiaan".

Ibu Hatimah juga memberikan keringanan untuk pembayaran bagi pelangganya, karena menggap pelanggan hanya memiliki modal tenaga saja.

"Adek, \{lok andik bhendeh orengnga\}, ken abhendeh tenaga jiyah".

(Nggk, \{gak punya modal orangnya\}, cuma modal tenaga itu).

Beliau memberi keringanan karena merasa bahwa pelanggannya tersebut tidak memiliki modal jika harus membayar terlebih dahulu, karena pelanggan hanya memiliki modal tenaga. Kemudian peneliti berhasil menggali kesadaran terdalam informan:

“Iyot \{kodhuh pertaje\}, legghik mon lo' pajuh kan epebelih".

(Iya $\{$ harus percaya\}, nanti kalau ada yang tidak laku dikembalikan).

Pada titik ini kesadaran "Aku" atas ibu Hatimah adalah "Aku memberikan keringanan dalam hal pembayaran karena menganggap bahwa pelanggan tidak memiliki modal dan hanya memiliki modal tenaga, hal tersebut dilakukan karena Aku sudah percaya terhadap pelanggan".

Tidak hanya pelanggan, namun tetangga ataupun keluarga juga akan mendapatkan harga yang berbeda. Hal ini terlihat pada usaha rumahan milik $\mathrm{Hj}$. Rohimah. Meskipun, harga normal kue adalah Rp 1.000 mendapatkan 1 kue, maka untuk tetangga ataupun keluarganya beliau memberikan bonus kue semisal $\mathrm{Rp} 10.000$ akan mendapatkan 13 kue. Inilah alasan beliau memberikan bonus : 
'Iyeh neng \{masak engko' ke tetangghe meddhemmah\} deiyeh engko'. Napa' gressah kan \{se tello' angghep tang sedeka\} deiyeh engko',".

(Iya neng \{masak saya ke tetangga mau menutup mata\}gitu saya. Kalau terasa, kan anggap yang 3 itu sedekah saya, gitu saya).

Kemudian beliau melanjutkan:

'Enje' mon engko' lakar wes \{pokok mon le tetangghe jiyah le pasti laen\}, makeh sap'aah pas le melle ke engko'. \{Jangankan tetangghe\} neng, wak Supiani joh bara' embong, kan mon melleh nyabbreng neng, Hj, dentek yak engkok melleyah jhejennah 5.000, ajiyah bik engko' eberrik 7 neng, \{neser\} male olle beteh 2.000 derih engko', \{yeh mon selamet se nyabreng, mon enjek? Benya'an mekkeren deiyennah jiyah engko' neng\}. Kadheng le pas ngocak lo' rogi ghi Hj. Empon lo' rogi le deiyeh engko' neng”.

(Nggak, \{pokok kalau saya kalau sudah tetangga itu pasti beda\}, meskipun sapa beli ke saya pasti gitu. \{Jangankan tetangga\} neng, itu Supiani di barat jalan, kan kalau beli nyebrang neng. Hj tunggu ya saya beli kuenya 5.000, itu sama saya dikasih 7 neng, \{kasian\} supaya dapat untung 2.000 dari saya, \{iya kalau selamat yang nyebrang, kalau nggak? Lebih banyak mikir itunya saya neng\}, kadang ya pas bilang gak rugi ya mik, udah gak rugi saya bilang gitu neng).

Pada titik ini pemahan "Aku" oleh $\mathrm{Hj}$. Rohimah adalah "Aku sadar bahwa jumlah roti atau kue yang diberikan kepada tetangga, keluarga, atau orang terdekat tidak sesuai dengan harga jual yang ditetapkan di awal, karena Aku sadar bahwa keluarga dan tetangga adalah suatu keutamaan serta harus selalu memikirkan keadaan orang sekitar".

Dari hal-hal yang terjadi pada usaha rumahan roti dan kue di Madura, ternyata biaya bukan satu-satunya faktor yang dapat dijadikan pedoman dalam penentuan harga jual. Penentuan harga jual pada pembahasan kali ini lebih kepada nilai Po Sapo Esempay (Kesetiakawanan). Kehadiran nilai kesetiakawanan yaitu saling peduli dan saling merasakan susah senang bersama. Nilai inilah yang menjadi kesadaran terdalam pelaku usaha sebagai pemilik usaha yaitu $\mathrm{Hj}$. Rohimah dan Ibu Hatimah dan juga pelanggan-pelanggannya.

\section{Melekatkan Nilai Sokkla (Keagamaan) dalam Penentuan Harga Jual}

Secara sederhana kebahagiaan tidak hanya dihitung melalui materi yang didapat, namun di sisi lain terdapat keahagiaan sesungguhnya yang harus dicapai kelak di akhirat. Hal ini terjadi pada kedua pemilik usaha rumahan yang masih melekatkan nilai Sokkla (Keagamaan) dalam aktifitas usaha yang dijalankan ditengah zaman yang modern. Pembawaan berkeagamaan orang Madura dalam menjalani kehidupan seharihari memiliki akar sejarah yang sangat panjang sehingga melekat dalam diri orang Madura(Rifai, 2007: 232).

Seperti yang dialami ibu Hatimah, beliau memberikan harga yang lebih murah kepada tetangga yang membeli roti atau kuenya. Beliau hanya mengambil untung sedikit ketika tetangga membeli, seperti pengakuan beliau kepada peneliti:

"Iyeh \{neser ajhelling\} jhek le tetangghe\{Masak tetanggheh ghik ekalaah bheteh $\}$ hehehe".

(Ya \{kasihan yang melihat\} kan tetangga neng. \{Masak ke tetangga masih mau ngambil untung\} hehehe) 
Kemudian ibu Hatimah mengatakan bahwa kepada tetangga, beliau tidak mengambil untung. Untung yang didapat tidak sebanyak biasanya, Peneliti mencoba menggali kesadran terdalam informan. Lalu ibu Hatimah menceritkan kembali:

"Soallah tetangghe jiyah melleh de' roma kan terro iriten. Terro se modeen deiyeh, polannah \{along polong\} sambinnah neng. Oreng jiyah mon \{lok ajhelling ke tetanggheh tak pas adek amallah\}, pas ajhelling pesse to'”.'

(Soalnya tetangga itu beli ke rumah kan ingin lebih irit. Ingin yang lebih murah gitu, apalagi sudah \{biasa bersama neng\}. Orang itu \{kalau tidak melihat ke tetangga kan tidak ada amalnya $\}$, cuma melihat uang saja).

Pada titik inilah, kesadaran "Aku" atas Ibu Hatimah adalah "Aku sadar telah memberikan harga lebih murah kepada tetangga karena merasa kasihan, hal tersebut dilakukan karena Aku percaya dengan cara melihat kepada tetangga, juga akan mendapatkan amal, dan tidak selalu tentang uang".

Pernyataan ibu Hatimah juga didukung oleh ibu Meisari yang selalu memesan kue kepada beliau. Beliau menceritakan mengenai penetapan harga jika membeli ke ibu Hatimah:

"Oo mon Mama Papa 65"

(Kalau Mama Papa 65 ribu).

Kemudian beliau melanjutkan:

"Mon de' oreng 75"

(Kalau ke orang 75ribu)

Ibu Meisari selalu merasa mendapatkan potongan harga jika membeli kepada ibu Hatimah. Seperti yang dicontohkan beliau bahwa harga kue Mama Papa biasanya Rp 75.000, namun setiap ibu Meisari memesan, beliau selalu mendapatkan harga Rp 65.000. Kemudian beliau melanjutkan ceritanya:

"Iyeh le biasa, kan le along polong ruwah, deddhi le biasa mon badha mantan apah".

(Iya sudah biasa, kan sudah biasa bersama-sama, jadi ya sudah biasa kalau ada manten juga).

Beliau merasa bahwa sudah terbiasa bersama dengan ibu Hatimah, sehingga untuk keperluan apapun juga terbiasa memesan kepada ibu Hatimah.

Selain memberi harga yang murah, beliau juga sering menjual harga roti dan kuenya dengan sangat murah bahkan bisa jadi gratis dan secara sukarela:

" $\{$ Beghi ke oreng\} mon beccaan, kadheng \{ejhejheaghin ghen 500\}"

( $\{$ Dikasih ke orang\} kalau kue basah, kadang \{dijual harga 500\}).

Roti dan kue yang tidak laku terjual dapat dikembalikan oleh pelanggan. Lalu, roti dan kue tersebut akan dikasih kepada orang yang membutuhkan, atau ada inisiatif lain yaitu menjualnya dengan harga murah yaitu Rp 500. Lalu, ibu Hatimah melanjutkan :

"He'e ghebey \{amal\}".

(He'e buat $\{$ amal $\}$ ). 
Mendengar jawaban beliau, lalu peneliti bertanya tidak rugikah jika roti dan kuenya tersebut dibagi-bagi atau dijual dengan harga yang lebih murah. Dengan semangatnya beliau menjawab:

"Yeh rogi jiyah kan... Nyamanna \{ghebey amal ade'roginna\} jiyah".

(Ya rugi itu kan... namanya juga \{dibuat amal gak ada ruginya\} itu neng).

Pada titik inilah, kesadaran "Aku" atas Ibu Hatimah adalah "Aku sadar bahwa aku membagi-bagikan roti dan kue kepada orang sekitar, serta mejualnya lebih murah, karena darisitulah Aku berusaha mendapatkan amal sehingga merasa tidak dirugikan" Hal serupa juga terjadi pada $\mathrm{Hj}$. Rohimah, berikut penuturan beliau:

“Enjek, engko' neng \{daripada epebelih\}, \{lebih baek esedekaaghin\}. Sapah se suka nyedekaaghin yeh le sedekaaghin. Badha reng lajing yeh setiap badha karennah ngocak yak sedekannah hj. Rohimah reh".

(Nggak, saya neng \{daripada dikembalikan\}, \{lebih baik disedekahkan\}. Sapa yang suka menyedekahkanyaudah sedekahkan saja. Ada orang Lajhing ya setiap ada sisanya pasti bilang ini sedekahnya $\mathrm{Hj}$. Rohimah).

Hj. Rohimah mengungkapkan bahwa daripada roti dan kuenya dikembalikan kepada beliau, beliau lebih senang jika roti dan kuenya tersebutdisedekahkan. Demikian curhatan beliau terhadap peneliti jika masih terdapat roti atau kuenya yang tidak laku.

Rasa penasaran peneliti terhadap pemilik usaha ini, menjadikan peneliti berhasil mendapatkan kesadaran terdalam mengapa pemilik usaha rumahan ini lebih memilih menyedekahkan roti dan kuenya tersebut yang secara kasat mata tidak akan mendapatkan keuntungan dibandingkan dengan menjualnya kembali sehingga dapat menambah keuntungan yang didapat. Berikut penuturan beliau:

'Iyeh engko' messen neng, dhinah ompamanna tang andi' badha \{lok paju\} dhinah \{lo' usa pabeli\}, dhinah \{sedekaaghin\}. \{Male bedeh karennah paghik\}”.

(Iya saya mesen neng, sudah kalau seumpamanya punya saya \{tidak laku\}, sudah \{jangan dikembalikan\}, langsung \{sedekahkan saja\}. \{Supaya ada sisanya nanti (akhirat)\})

Dalam hal tersebut maka pemahaman "Aku" oleh $\mathrm{Hj}$. Rohimah adalah "Aku lebih memilih menyedekahkan roti dan kue daripada dikembalikan, karena Aku sadar bahwa hasil penjualanku juga dapat digunakan di akhirat".

Suatu hal yang dikatakan $\mathrm{Hj}$. Rohimah tersebut, diakui kebenarannyaolehumi Sulastri. Beliau mengungkapkan:

“Ebeghi oreng, kadheng bik engko' le esettoren mon engko' andik' rejheke, mon lo' andi' rejheke yeh epotong"

(dikasih ke orang, kadang saya yang nyetorin kalau punya rezeki, kalau gak punya rezeki ya dipotong)

Umi Sulastri mengatakan bahwa kue yang tidak laku akan dibagikan kepada orang, namun kadang pula jika beliau memiliki rezeki, maka beliaulah yang akan membayar kepada $\mathrm{Hj}$. Rohimah. Kemudian, beliau melanjutkan ceritanya:

"Iyot, mon ebueng kan mubadzir"

(iya kalo dibuang mubadzir) 
Beliau mengatakan bahwa daripada roti atau kue $\mathrm{Hj}$. Rohimah dibuang, maka akan menjadi sesuatu yang mubadzir dan ini tidak akan pernah bermanfaat. Lalu beliau juga menyatakan bahwa:

“Enje' neng, kan ghi' ngalakl' ke laennah jhek le padeh sedeka”

(Enggak neng, kan juga ngambil ke lainnya sama - sama sedekah).

Beliau mengakui bahwa semua itu dilakukan juga untuk sedekah.

Apapun yang yang diamanahkan $\mathrm{Hj}$. Rohimah kepada pelanggannya, termasuk berpesan kepada pelanggan agar sisa kuenya disedekahkan, merupakan kepercayaan terhadap pelanggan. Berikut penuturannya:

"Se penteng neng tang \{ateh le lok ngrespon\}, masalah \{oreng ko neko jiyah apah jhek le ekebeh dhibik\}. Se penteng engko' \{le pasra ke oreng $100 \%$ pertajeh\} ke jiyah, yot lo' arapah engko' lok toman anoh. Bahkan engko' reh bik pedegeng laennah ekocak, degengngah le ngocak kareh berempah le ok, benne deng pereddengan tapeh eghelle' mesem, iyeh neng cang oreng".

(Yang penting neng \{hati saya tidak merespon\}, masalah \{orang neko-neko itu pasti kembali ke dirinya sendiri\}. \{Yang penting saya pasrah $100 \%$ percaya ke dia, yaudah gitu saya gak pernah ini itu. Bahkan saya ini oleh pedagang lain itu dibicarain, dagangannya bilang saja sisa berapa pasti bilang ok, bukan malah emosi tapi tertawa dan senyum, iya neng kata orang begitu).

Di dalam cerita tersebut, beliau mengatakan bahwa beliau memberikan kepercayaan $100 \%$ terhadap pelanggan dalam hal harga yang sudah diberikan serta jumlah kue yang sudah diamanahkan terhadap pelanggan. Sehingga beliau tidak menghitung kembali berapa yang laku terjual dan berapa sisa yang masih ada. Beliau mengatakan hal tersebut karena selain kepercayaan yang diberikan terhadap pelangganya, beliau yakin bahwa semua yang dilakukan oleh pelanggannya akan dibawa sendiri akibatnya.Peneliti mencoba menggali kesadaran $\mathrm{Hj}$. Rohimah yang memberikan kepercayaan $100 \%$ terhadap pelanggan, lalu peneliti menemukan puncak kesadaran dari cerita $\mathrm{Hj}$. Rohimah. Berikut ulasannya:

“Iyeh poko'eng le deiyeh, \{pokoeng setiap kata-katannah menossah reh le bedeh se nyatet\}".

(Iya pokoknya gitu, \{pokoknya setiap kata-katanya manusia itu sudah ada yang nyatet\}).

Beliau menyatakan bahwa setiap kata-kata manusia sudah ada yang mencatat.Pada titik ini, pemahaman atas "Aku" oleh $\mathrm{Hj}$. Rohimah adalah "Aku memberikan kepercayaan $100 \%$ terhadap pelanggan, karena Aku sadar bahwa setiap perbuatan dan kata-kata manusia sudah ada yang mencatat"

$\mathrm{Hj}$. Rohimah juga merasakan tidak pernah mengalami kerugian, meskipun roti atau kuenya disedekahkan kepada orang yang membutuhkan:

“jiyah neng, engko lo' toman ngrassah ada kerugian selalu untung, Arapah engko' mek ngoca' deiyeh, polannah engko' lok andi' pemasukan laen kecuali ajuwal jhejen riyah. Arapah engkok mek mampu ghebey majer aresan, mek selalu bhen areh badha deiyeh. Brati engko' kan ontong deiyeh to' engko' neng, le lo' ghi' renyareh pekkeran. \{Sepenteng engkok alakoh se bendher, ghe moghe engko' bi' 
pangeran eberrik rejeke se cokop se halal se jhember dunia akherat, engko' lo' mentah luk muluk neng, ken le deiyeh reh saareh\}".

(itu neng, saya tidak pernah merasakan kerugian, selalu merasa untung. Kenapa saya bilang begitu, karna saya tidak punya pemasukan lain selain jual kue. Kenapa saya mampu untuk bayar arisan, kok tiap hari selalu ada saja. Berarti saya kan untung, gitu saja saya neng, udah gak usah jadi pikiran. \{Yang penting saya kerja yang bener, semoga saya diberi rezeki yang cukup yang halal, yang membuat senang dunia dan akhirat oleh Allah. Saya tidak minta aneh-aneh, cuma itu saja tiap hari\}).

Pada titik ini, pemahaman atas "Aku" oleh $\mathrm{Hj}$ Rohimah adalah "Aku merasa tidak pernah rugi dan selalu untung sehingga mampu memenuhi kebutuhan sehari-hari, orang lain, serta mampu naik haji, karena Aku sadar bahwa hanya berharap kerja yang benar, rezeki yang halal, dan rezeki yang membuat senang dunia dan akhirat".

Dari hal-hal tersebutlah maka terdapat nilai sokkla (keagamaan) dalam penetuan harga jual, dimana pemilik usaha percaya mengenai kebermanfaatan usahanya yang dapat dijadikan amal, kepercayaan kepada Sang Pencipta, dan wujud kepasrahannya dalam menjalankan usaha.

\section{KESIMPULAN}

Melalui pendekatan fenomadurologi peneliti berhasil mencapai suatu kesimpulan tentang bagaimana penentuan harga jual roti dan kue di Madura. Penentuan harga jual yang diaplikasikan oleh pemilik usaha rumahan, tidak sepenuhnya sama dengan teori yang selama ini diajarkan. Ketidaksamaan tersebut adalah hal yang lumrah mengingat akuntansi adalah suatu ilmu yang merupakan bagian dari budaya. Hal tersebut terjadi pada pemilik usaha rumahan roti dan kue, dalam penentuan harga jual roti dan kue, pemilik memiliki cara tersendiri.

Dalam penentuan harga roti dan kue terdapat biaya-biaya yang dihitung oleh pemilik usaha rumahan, biaya tersebut yaitu biaya bahan baku dan biaya overhead pabrik. Pemilik secara sadar menghitung kedua biaya tersebut dalam pembuatan roti dan kuenya. Namun, dalam menentukan mark up, pemilik usaha rumahan tidak dapat menentukannya dalam bentuk persentase, Meski demikian, peneliti berhasil mendapatkan informasi mengenai biaya apa saja yang menjadi salah satu komponen dari mark up tersebut. Biaya-biaya yang sudah dimasukkan dalam mark up namun tidak dihitung secara kuantitatif yaitu biaya listrik, biaya bensin, dan biaya tenaga kerja. Biaya tersebut tidak dihitung karena pemilik merasa biaya tersebut juga digunakan untuk keperluan pribadi.

Setelah mengetahui biaya-biaya tersebut, ternyata ada hal unik lain yang dijadikan dasar dalam penentuan harga jual yaitu nilai Po Sapo Esempay (Kesetiakawanan) yang terwujud dalam bentuk saling membantu antara pemilik usaha dengan pelanggan, mengurangi untung demi saudara, rasa "neser" sebagai ungkapan perhatian dan kepedulian terhadap orang sekitar, kepercayaan yang diberikan kepada pelanggan, serta tidak menutup mata terhadap tetangga atau keluarga karena menganggap keluarga dan tetangga adalah suatu keutamaan. Nilai inilah, yang menjadi salah satu alasan bagi pemilik usaha rumahan dalam memberikan harga roti dan kuenya. 
Nilai lain yang terkandung dalam penentuan harga jual juga tidak hanya mengenai masalah dunia, namun juga akhirat yaitu nilai Sokkla (Keagamaan) yang juga menjadi hal utama yang yang dijadikan dasar dalam penentuan harga. Hal tersebut terwujud ketika pemilik menganggap bahwa tetangga adalah jalan untuk mendapatkan amal, merasa bahwa amal tidak akan pernah membuat usaha rugi, kepercayaan akan adanya keadilan Tuhan, serta adanya kepasrahan pemilik usaha kepada Sang pemberi Rezeki.

\section{SARAN}

Penelitian ini diharapkan dapat dijadikan salah satu sumbangsih, terutama untuk peneliti selanjutnya yang ingin mengetahui keunikan-keunikan lain yang terdapat dalam harga jual. Peneliti selanjutnya juga dapat meneliti tentang pengelolaan keuangan yang tidak hanya pada usaha roti dan kue, namun pada usaha-usaha lain yang masih melekatkan nilai-nilai kearifan lokal di dalamnya.

\section{DAFTAR PUSTAKA}

Ahmad, Kamaruddin. 2013. Akuntansi Manajemen. Edisi Revisi. Jakarta: Rajawali Pers Alimuddin. 2011. Konsep Harga Jual Islami. Jurnal Penelitian Universitas Hasanuddin Amaliah, Tri Handayani. 2016. Nilai Nilai Budaya Tri Hita Karana dalam Penetapan Harga Jual. Jurnal Penelitian Universitas Negeri Gorontalo

Amaliah, Tri Handayani. 2014. Konsep Harga Jual Berbasis Nilai- Nilai Budaya Komunitas Papalele Masyarakat Maluku. Disertasi Universitas Negeri Gorontalo

Daljono. 2011. Akuntansi Biaya. Edisi ketiga. Cetakan satu. Semarang: Bp Undip

Efferin, Sujoko. 2016. Sistem Pengendalian Manajemen Berbasis Spritualitas. Jakarta: Yayasan Rumah Peneleh

E Paper Koran Madura. Membaca Peluang Bisnis Roti. https://issuu.com/koranmadura/docs/full version mad 270114/31. Diunduh pada tanggal 9 Maret 2017

Halim, Abdul, Bambang Supomo, Muhammad Syam Kusufi. 2014. Akuntansi Manajemen. Edisi kedua. Cetakan keempat. Yogyakarta: BPFE

Hansen, Don R dan Maryanne M. Mowen. 2001. Manajemen Biaya. Buku 2. Jakarta: Penerbit Selemba Empat

Kamayanti, Ari. 2016. Metodologi Penelitian Kualitatif Akuntansi. Jakarta: Yayasan Rumah Peneleh

Kamus Besar. https://www.kamusbesar.com/dadar-gulung. Diunduh pada tanggal 18 April 2017

Lestari, Arum Budi. 2014. Evaluasi Penetapan Harga Pokok Produk Roti pada UKM Roti Saudara di Banyumik. Jurnal Penelitian Universitas Dian Nuswanto Semarang

Maleong, Lexy, J. 2014. Metodologi Penelitian Kualitatif. Bandung: PT Remaja Rosdakarya 
Moray, Jessica Claudia. 2014. Penetapan Harga Jual dengan Cost Plus Pricing menggunakan Pendekatan Full Costing pada UD. Gladys Bakery. Jurnal Penlitian Universita Sam Ratulangi Manado

Mulyadi. 2012. Akuntansi Biaya. Edisi kelima. Cetakan sebelas. Yogyakarta: UPP STIM YKPN

Nurpeni. 2010. Analisis Tentang Kendala Ibu Rumah Tangga Enggan Berwirausaha di Kelurahan Umban Sari Kecamatan Rumbai Kota Pekanbaru. Jurnal Universitas Lancang Kuning Pekanbaru

Peluangusaharumahan.info (2017). Usaha Produksi Kue Rumahan Sangat Menjanjikan. www.peluangusaharumahan.info/usaha-produksi-kue-rumahan-sangatmenjanjikan. Diakses pada tanggal 2 Maret 2017

Rifai, Mien Ahmad. 2007. Manusia Madura. Cetakan Pertama. Yogyakarta: Pilar Media

Royani, Syarifah. (2016, 10 Oktober). SDM Kreatif dan Berkualitas untuk Mengurangi Pengangguran. Www.kompasania.com/indanaeka/sdm-kreatif-danberkualitas-untuk-mengurangi-pengangguran. Diakses pada tanggal 2 Maret 2017

Sodikin, Slamet Sugiri. 2015. Akuntansi Manajemen. Edisi kelima. Yogyakarta; UPP STIM YKPN

Soei, Christanti Natalia. 2014. Penentuan Harga Jual dengan menggunakan Metode Cost Plus Pricing pada UD. Sinar Sakti. Jurnal Penelitian Universitas Sam Ratulangi Manado

Sulpa, Nadylah. 2014. Proses Penentuan Harga Jual pada Rumah Makan Citra Minang di Makassar. Skripsi Universitas Hasanuddin Makassar

www.jurnalasia.id. (2016, 6 Juni). Membaca Peluang Usaha Rumahan Bermodal Kecil. www.jurnalasia.com/ragam/membaca-peluang-usaha-rumahan-bermodalkecil. Diakses pada tanggal 2 Maret 2017

Zalshabila, Shavira. 2012. Javanese Price Setting: Refleksi Fenomenologis Harga Pokok Produksi Pedagang Bakso di Kota Malang. Jurnal Penelitian Universitas Brawijaya Malang 
Halaman ini senagaja dikoongkan

22 | Nilai Po Sapo Esempay (Kesetiakawanan) dan Sokkla (Keagamaan)... 